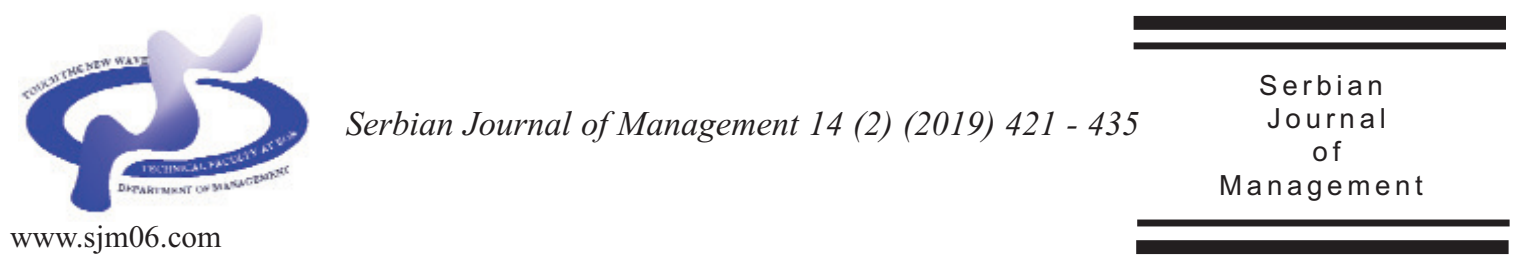

\title{
PILLARS OF CUSTOMER RETENTION: AN EMPIRICAL STUDY ON THE INFLUENCE OF CUSTOMER SATISFACTION, CUSTOMER LOYALTY, CUSTOMER PROFITABILITY ON CUSTOMER RETENTION
}

\author{
Bader Almohaimmeed* \\ Business Administration Department, College of Business \& Economics (CBE), \\ Qassim University, KSA, Buraydah Saudi Arabia, Qassim Region, Buraydah, Almleda.
}

(Received 30 October 2017; accepted 09 November 2018)

\begin{abstract}
The aim of this study is to explore relationships among five factors: customer relationship management, customer satisfaction, customer loyalty, customer profitability, and customer retention. The sample of the study consists of 750 managers and employees of different restaurant in Riyadh, the capital city of Saudi Arabia. The questionnaire developed for the purpose of this study is distributed by hand to respondents. Out of 750 questionnaires distributed, 497 are returned with a high rate of response. The Analysis of Moment Structures (AMOS, Version 22) is used to analyze the collected data. The findings of the study revealed a significant influence of customer relationship management on customer satisfaction, a significant influence of customer satisfaction on both customer loyalty and customer profitability. Therefore, the data doesn't support the hypothesis that customer loyalty mediates the relationship between customer satisfaction and customer profitability. On the other hand, there are significant relationships between customer satisfaction and customer profitability and between customer profitability and customer retention, while there is no significant relationship between customer satisfaction and customer retention.
\end{abstract}

Keywords: customer relationship management, customer satisfaction, customer loyalty, customer profitability, customer retention.

\section{INTRODUCTION}

Organization are striving to retain customers in order to be able to cope with many challenges. Examples of these challenges include the increased levels of competition among organizations, the advancements in information technology, the

*Corresponding author: badermeed@gmail.com

DOI: 10.5937/sjm14-15517 
emergence of total quality initiative, the evolution of network economy (Minna \& Aino, 2005), the need for product customization (Ashraf et al., 2015), and globalization (Kangu et al., 2017). One of the most important variables reported by authors which can be utilized as a solution to deal with these challenges is customer relationship management (CRM).

In fact, numerous authors cited different advantages of using CRM. Examples of these advantages include the enhancement of customer loyalty, profitability and satisfaction as well as organizational performance (ElKordy, 2014). Navimipour and Soltani (2016) indicate that the main aim of CRM systems is to increase the effective implementation of CRM processes, which in turn affects the effectiveness of their communications with customers. Alipour and Mohammadi (2011) consider CRM as a major competitive strategy which organizations could use to enhance their interactions with customers. Soliman (2011) found that CRM is significantly, directly and positively related to marketing performance. In their study on CRM and performance in the banking sector, Wachira and Were (2016) come to a significant impact of CRM on banks' performance. Kangu et al. (2017) figure out a positive impact of CRM on customer loyalty.

CRM has been defined as a method used by organizations to manage business relationships with their customers. The management of these relationships include maintain prosperous long-term relationships with loyal and profitable customers (Navimipour \& Soltani, 2016). According to Ashraf et al. (2015), the concept of CRM is implanted in the management of customers relationships on the basis of the effective and efficient flow of information, and the achievement of increased value delivered to the customers in addition to the reduced costs of the organization. According to Stojkovic and Dubricic (2012), CRM philosophy refers to an iteration process of four activities, which are knowledge discovery, market planning, interaction with customers and customer's data analysis. ElKordy (2014) adds that this process comprises the integration of sub-process, technology and customer orientation, which aims at enhancing the organization capability to effectively manage its profitable interactions with customers. Piroozfar and Yaghini (2012) conceptualize CRM based on two views; the strategic view and the technological view. According to them, the strategic view of CRM elucidates the evolution of CRM concept in terms of transactional and relational marketing in view of the fact that CRM is a final result of these two types of marketing, and the technological view of CRM, in which organizations adopt new practices such as data mining, data warehousing and best practices of customer interactions in order to deal with changes in business environment as the increased competition and the need for products customization. Kangal (2012) cited a number of CRM definitions in which the concept is considered as an approach steered towards customers, either through the emphasis on their lifecycles, as a relational strategy, a market competition method, or as a customer-driven technology.

To the best of the author knowledge, little studies are conducted to investigate the indirect effect of CRM on customer retention through customer satisfaction, customer loyalty, and customer profitability using a sample of service organizations such as restaurants. The main contribution of this study can be recognized through finding the 
relationships between customer relationship management and customer satisfaction, customer satisfaction and customer loyalty, customer satisfaction and customer profitability, customer profitability and customer retention, as well as customer satisfaction and customer retention. On one hand, customer relationship might results in customer satisfaction, but customer satisfaction only is not enough to ensure customer loyalty Noor (2012), profitability or retention.

Numerous organizations observe the migration of some of their satisfied customers to another competitor organizations. One important factor considered as critical antecedent to cope with this case is customer loyalty. Even if an organization gains its customers loyalty, some of them accord nothing in terms of profitability and it may become unable to retain those loyal customers. In a word, for an organization to achieve success, it should be able to take possession of its own loyal and profitable customers in order to be able to retain them. In fact, this scenario is emerged from numerous discussions conducted by the researcher with different managers and employees from different organizations. This conclusion is consistent with CRM theory which indicates that organizations are required to retain loyal as well as profitable customers (Kangu et al., 2017).

In accordance with the contribution of this study, it tries to explore the relationship between customer relationship management and customer satisfaction the relationship between customer satisfaction and customer profitability through customer loyalty and the relationship between customer satisfaction and customer retention through customer profitability. Consequently, the study seeks to investigate the mediation roles played by customer loyalty and customer profitability.

\section{LITERATURE REVIEW AND HYPOTHESES DEVELOPMENT}

\subsection{Customer management definition \\ relationship}

A deep review of the literature in relations to definitions of CRM results in many definitions as can be seen in Table 1. It was concluded that CRM represents a mean by which an organization be in a position enables it to create superior value for itself and for its customers through building lasting relationships with those loyal and profitable customers.

\subsection{Customer management dimensions \\ relationship}

Different dimensions of CRM found in the literature. Khodakarami and Chan (2014) categorized customer relationship management systems into three types: collaborative systems, analytical systems, and operational systems. Collaborative systems are used to manage the communication process between the company and the customer, while analytical systems are used to analysis customer data. On the other hand, the operational systems are used to enhance the efficiency of CRM processes. Bahrami et al. (2012) argue that CRM uses customers data and can be facilitated by information technology applications. i.e., E-CRM. In terms of dimensions of CRM found in the literature, Chen and Popovich (2003) identified three indispensable dimensions of CRM, which 
Table 1. Definitions of CRM

\begin{tabular}{ll}
\hline Author (s) & \multicolumn{1}{c}{ CRM definition } \\
\hline Chen and Popovich (2003) & $\begin{array}{l}\text { A combination of three ingredients directed to efficient and effective building and maintaining } \\
\text { of relationships with customers }\end{array}$ \\
\hline Stojkovic and Dubricic (2012) & $\begin{array}{l}\text { A cyclic process of knowledge discovery, market planning, interaction with customers and } \\
\text { customer's data analysis. }\end{array}$ \\
\hline $\begin{array}{l}\text { Parvatiyar and Sheth (2001) cited } \\
\text { in Piroozfar and Yaghini (2012) }\end{array}$ & $\begin{array}{l}\text { A strategy used to create a value for the organization and the customer on the basis of } \\
\text { organizational activities concern acquiring and retaining specific customers. }\end{array}$ \\
\hline Khodakarami and Chan (2014) & $\begin{array}{l}\text { An information system utilized by the company in order to collect, store, analyze } \\
\text { customer data to gain an expansive view of customers. }\end{array}$ \\
\hline ElKordy (2014) & $\begin{array}{l}\text { The integration of CRM processes, technologies, and organization along with customer } \\
\text { orientation which enables the organization to manage its long-term profitable interactions with } \\
\text { its customers. }\end{array}$ \\
\hline Ashraf et al. (2015) & $\begin{array}{l}\text { An information technology system used to manage organizations' external relationships, i.e., } \\
\text { relationships with customers, and internal relationships, i.e., relationship among the } \\
\text { organizational functions, in order to provide the customers with the intended value. }\end{array}$ \\
\hline Navimipour and Soltani (2016) & $\begin{array}{l}\text { An approach used by organizations to manage business relationships with their loyal and } \\
\text { profitable customers. }\end{array}$ \\
\hline
\end{tabular}

are technology, processes and people.

Kincaid (2003) cited in Piroozfar and Yaghini (2012) emphasizes the use of information, technology, processes and people to implement CRM. ElKordy (2014) adds two dimensions, which were the organization of CRM activities and customer orientation. Minna and Aino (2005) assign three inescapable components of CRM from the technological view: the collaborative systems, the analytical systems, and the operational systems. Boudiaf (2016) appends two dimensions, which are key customer focus and customer knowledge. Urbanskiene et al. (2008) pinpoint four dimensions of CRM, which were key customer focus, CRM organization, knowledge management, and technology-based CRM. Kangal (2012) particularizes six dimensions of CRM: customers, management, relations, employees, processes, and technology. Dumitrescu and Fuciu (2009) describe of CRM aspects: front (direct relationships with customers) and back office operations (daily functions of the organization such billing and processing), business relationships with other organizations, CRM-related data analysis such as number of customers and profitability.

Hassan et al. (2015) identified three components CRM: customer, relationship, and management. Adalikwu (2012) study CRM in terms of customer acquisition (contact rate with customer, regular assessment of customer profitability, and customer persuasion), customer enhancement (increased sales either by customized offers, switching barriers, or decreased cost of service), and customer recovery (added value in 4Ps and customized services). Based on the above-mentioned literature, one can conclude that CRM comprise: technology, employees, processes, relationships, information, and customers.

\subsection{Customer relationship management and customer satisfaction}

Many studies have been confirmed that the implantation of CRM processes would results in greater level of customer satisfaction (Richards \& Jones, 2009; Adalikwu, 2012; Stojkovic \& Dubricic, 2012; ElKordy, 2014; Khedkar, 2015; Singh 
\& Singh, 2016). In their study on the effect of CRM on customer satisfaction in banking sector, Hassan et al. (2015) found a positive effect of CRM on customer satisfaction. Consequently, the following hypothesis is suggested:

H1: CRM has a significant influence on customer satisfaction.

\subsection{Customer satisfaction and customer loyalty}

Kangu et al. (2017) defined customer loyalty in terms of their willingness to repeat purchases, referred new customers and loyalty programs. Using a sample of managers who are responsible for relationships with customers of 147 hotels in Kenya, the researchers found a significant relationship between IT-based CRM applications and customer loyalty. The study concluded that the technology infrastructure as a main component of CRM engenders customer loyalty. In fact, the direct relationship between CRM and customer loyalty is not one of the hypotheses suggested by the current study. Instead of that, this study explores the relationship between customer satisfaction and customer loyalty.

In this vein, Arokiasamy (2005) investigated the impact of customer satisfaction on customer loyalty and intention to switch and points out a positive impact of customer satisfaction on customer loyalty, while there is no significant relationship between customer satisfaction and intention to switch. Hence, the study regards customer satisfaction as a major requirement for customer loyalty. The positive relationship between customer satisfaction and customer loyalty is cited in many works (Bontis et al., 2007; Mohsan et al., 2011; Hafeez \& Muhammad, 2012). Therefore, the following hypothesis is postulated:

H2: customer satisfaction has a significant influence on customer loyalty.

\subsection{Customer loyalty and customer profitability}

According to ElKordy (2014), CRM theory considers customer loyalty as one of the most significant keys that organizations could use to enhance their profitability, and this may be due to the fact that loyalty is concerned with creating superior value for customers (Anderson \& Jacobsen, 2000). In relation to the importance of customer loyalty in wining customer profitability, Babatunde and Ajayi (2010) give emphasis to the influence of customer loyalty on customer profitability. Ibojo and Asabi (2015) cited many studies that assure the positive impact of customer satisfaction on customer loyalty, which in turn improves the profitability. Thompson (2005) justify organizations' efforts to gain customer loyalty by numerous factors: increased customer profitability, increased number of customers, and increased quality of products and services. In order to examine these studies in Saudi settings, the following hypothesis is supposed:

H3: customer loyalty has a significant impact on customer profitability.

\subsection{Customer satisfaction and customer profitability}

Studies conducted to explore the impact of customer satisfaction on profitability make clear that both variables are positively associated. Coldwell (2001) illustrate that satisfied customers are more profitable than 
non-satisfied customers. Ibojo et al. (2013) found a significant relationship between customer satisfaction and profitability.

H3: customer satisfaction has a significant impact on customer profitability.

\subsection{Customer profitability and customer retention}

In its paper of marketing profitability, Lenskold Group (2003) characterize customer retention as a continuous flow of customer profitability. For an organization to maintain its profitability stream, it is called upon the development of strategies that better customer retention. Dubihlela and Molise-Khosa (2014) use a sample of managers of hotels to test the relationship between e-CRM, customer loyalty, customer retention, and customer profitability. Their results accept the hypothesis that customer profitability is significantly associated to customer retention. Hence, the following hypothesis is suggested:

H4: customer profitability has a significant impact on customer retention.

\subsection{Customer satisfaction and customer retention}

While customer satisfaction is measured in terms of the fulfillment of the gap between customer expectation and customer actual experience, customer retention refers to the continuity of relationships between the organization and the customer (Ibojo \& Asabi, 2015). Bowen and Chen (2001) underline the importance of customer satisfaction in order to ensure customer retention. Subsequently, the following hypothesis is presumed:

H5: customer satisfaction has a significant influence on customer retention.

\section{METHODOLOGY OF THE STUDY}

\subsection{Study sample, data collection, measurements and statistical techniques}

This study uses a sample consisted of 750 managers and employees working at different types of restaurants in the capital city of Saudi Arabia, Riyadh. The data of the study is collected by a questionnaire developed based on previous studies and structured using a five-point Likert scale. CRM assessed using 12 items (Chen \& Popovich, 2003; Kincaid, 2003 cited in Piroozfar \& Yaghini, 2012; ElKordy, 2014; Boudiaf, 2016; Minna \& Aino, 2005; Khodakarami \& Chan, 2014), customer satisfaction measured by 4 items (Singh \& Singh, 2016), customer loyalty evaluated by 6 items (Kangu et al., 2017), customer profitability measured using 4 items (Pezeshki at al., 2005), and finally, customer retention estimated by 4 items (Wachira \& Were, 2016). Accordingly, the questionnaire of the study consists of 30 items. The questionnaire distributed by hand to respondents and 497 questionnaires are returned complete and usable for the purpose of statistical analysis. The Analysis of Moment Structures (AMOS, V.22) is used to analyze the collected data.

\subsection{Reliability and validity of the questionnaire}

Reliability is measured using the average variance extracted coefficients and validity is measured by discriminant validity. The results in Table 2 show that the criteria in request for reliability and validity tests are met. The values of composite reliability ranged from 0.924 to 0.940 with values of AVE from 0.694 to 0.822 as well as the 
square root of AVE values, shown in bold indices of model fitness. Based on these and the correlation coefficients between results, there is an acceptable fit between the variables below these values, indicate an hypothetical model and the sample data. acceptable level of reliability and validity.

\section{DATA ANALYSIS}

\subsection{Model fit summary}

The results of the structural modeling equation related to the fitness of the model shown in Table 3 underline an acceptable

\subsection{Estimates}

The findings of regression weights for the default model bring to light, as can be seen in Table 4 and Figure 1, a significant influence of customer relationship management (CRM) on customer satisfaction (CS) (estimate $=1.264$, S.E. $=0.115$, C.R. $=10.979$, $\mathrm{P}<0.05)$, a significant influence of customer

Table 2. Reliability and validity results

\begin{tabular}{lccccccc}
\hline \multicolumn{1}{c}{ Variable } & COR & AVE & CRM & CS & CL & P & CR \\
\hline CRM & 0.939 & 0.771 & $\mathbf{0 . 8 7 8}$ & & & & \\
CS & 0.933 & 0.742 & 0.442 & $\mathbf{0 . 8 6 1}$ & & & \\
CL & .924 & 0.694 & 0.137 & 0.201 & $\mathbf{0 . 8 3 3}$ & & \\
P & 0.940 & 0.801 & 0.288 & 0.268 & 0.103 & $\mathbf{0 . 8 9 4}$ & \\
CR & 0.928 & 0.822 & 0.093 & 0.025 & 0.132 & 0.322 & $\mathbf{0 . 9 0 6}$ \\
\hline
\end{tabular}

Reliability measurements: COR (composite reliability) and AVE (average variance extracted), validity measurements: the square root of AVE and correlation coefficients.

Table 3. Model fit summary

\begin{tabular}{llll}
\hline Indices & Criterion & Value & Result \\
\hline CMIN/DF & Less than 2-5 & 1.752 & Accepted \\
GFI & More than 0.90 & 0.974 & Accepted \\
AGFI & More than 0.90 & 0.922 & Accepted \\
RMR & Less than 0.1 & 0.041 & Accepted \\
CFI & More than 0.90 & 0.989 & Accepted \\
TLI & More than 0.90 & 0.978 & Accepted \\
RMSEA & Less than 0.08 & 0.06 & Accepted \\
\hline Note: CMIN/DF: the minimum discrepancy (Chi-square/degrees of freedom), GFI: Goodness of Fit Index, \\
AGFI: Adjusted Goodness of Fit Index, RMR: root mean square residual, CFI: The comparative fit index, \\
TLI: The Tucker-Lewis coefficient, RMSEA: root mean square error of approximation. \\
\hline
\end{tabular}

Table 4. Estimates of the default model

\begin{tabular}{|c|c|c|c|c|c|c|}
\hline & Path & & Estimate & S.E. & C.R. & $\mathbf{P}$ \\
\hline CRM & $\rightarrow$ & $\mathrm{CS}$ & 1.264 & 0.115 & 10.979 & $* * *$ \\
\hline $\mathrm{CS}$ & $\rightarrow$ & $\mathrm{CL}$ & 0.626 & 0.137 & 4.580 & $* * *$ \\
\hline CL & $\rightarrow$ & $\mathrm{P}$ & 1.508 & 0.010 & 14.884 & $* * *$ \\
\hline $\mathrm{P}$ & $\rightarrow$ & CR & 1.134 & 0.032 & 7.603 & $* * *$ \\
\hline CS & $\rightarrow$ & $\mathrm{P}$ & 1.134 & 0.032 & 5.760 & $* * *$ \\
\hline $\mathrm{P}$ & $\rightarrow$ & $\mathrm{CR}$ & 0.412 & 0.003 & 13.90 & $* * *$ \\
\hline $\mathrm{CS}$ & $\rightarrow$ & $\mathrm{CR}$ & 0.029 & 0.014 & 2.046 & 0.41 \\
\hline
\end{tabular}




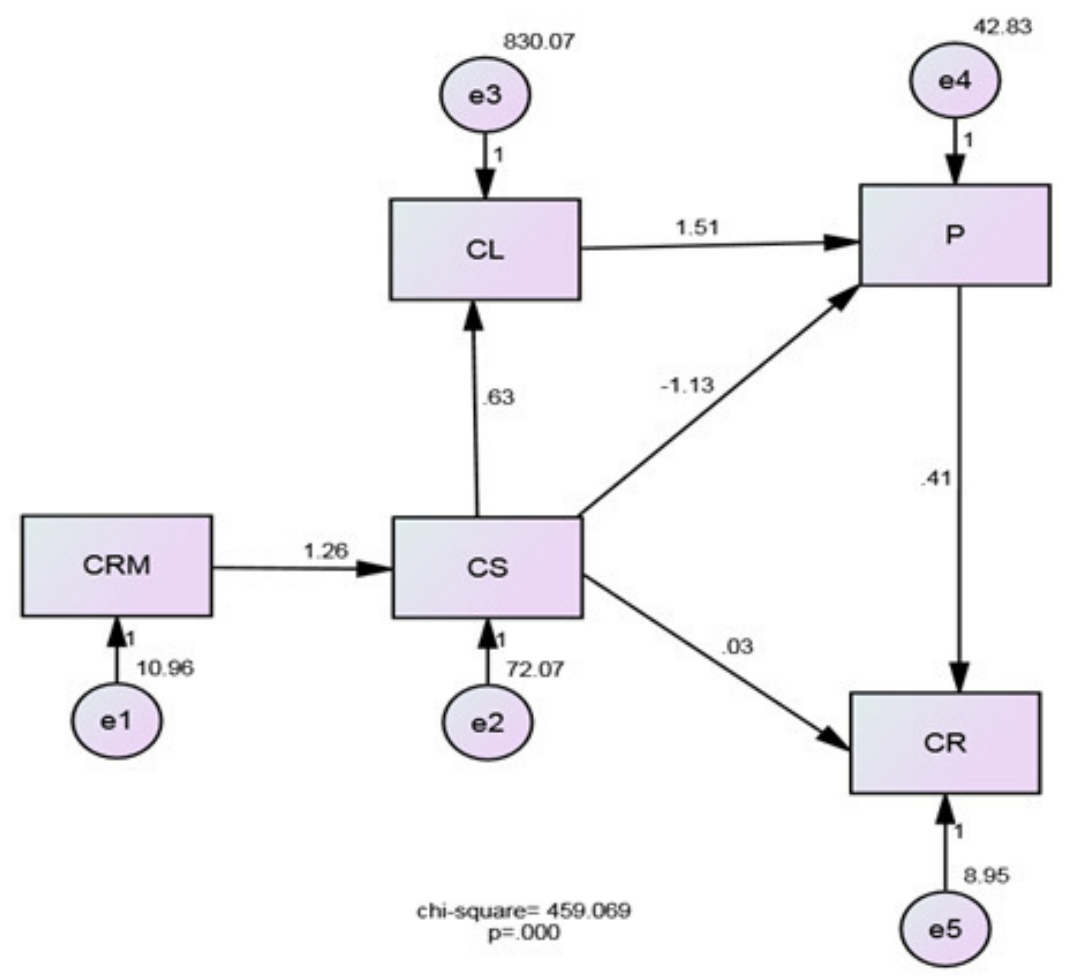

Figure 1. The structural equation model (SEM) ${ }^{1}$

satisfaction (CS) on customer loyalty (CL) (estimate $=0.626$, S.E. $=0.137$, C.R. $=4.580$, $\mathrm{P}<0.05$ ), a significant influence of customer loyalty (CL) on profitability (P) (estimate $=1.508$, S.E. $=0.010$, C.R. $=14.884$, $\mathrm{P}<0.05$ ), and a significant influence of profitability $(\mathrm{P})$ on customer retention $(\mathrm{CR})$ (estimate $=1.134$, S.E. $=0.032$, C.R. $=7.603$, $\mathrm{P}<0.05)$. On the part of $\mathrm{CS}$ and $\mathrm{CR}$, the results found a non-significant between these variables (estimate $=-0.029, \quad$ S.E. $=0.014$, C.R. $=2.046, \mathrm{P}=0.410$ ).

\section{DISCUSSION}

The aims of this study are fourfold. First, to investigate the influence of customer relationship management on customer satisfaction. Second, to explore the mediating role of customer loyalty in the relationship between customer satisfaction and customer profitability. Finally, to assess the mediating role of customer profitability in the relationship between customer satisfaction and customer retention. Using a sample consists of 500 managers and employees working at different types of restaurants in the capital city of Saudi Arabia, Riyadh. The results point out that customer relationship management is significantly related to customer satisfaction. That is, hypothesis 1 is accepted.

The current data doesn't support the second hypothesis which assumes that customer loyalty mediates the relationship between customer satisfaction and profitability since there is a significant relationship between customer satisfaction and customer loyalty, a significant relationship between customer loyalty and profitability, and a significant relationship 
between customer satisfaction and profitability. That is to say, customer satisfaction is significantly related to customer profitability, either directly or indirectly. The mediating role of customer profitability in the relationship between customer satisfaction and customer retention as suggested in hypothesis fails to be accepted, since there is a significant relationship between customer satisfaction and profitability, a significant relationship between profitability and customer retention, while there is no relationship between customer satisfaction and customer retention. Table 5. Explained the summary of hypotheses testing results

The results of the current study show a direct relationship between customer relationship management and customer satisfaction, a direct relationship customer satisfaction and customer profitability, and indirect relationship between customer satisfaction and customer retention. On the strength of these results, one can conclude that organizations pay more attention to customer relationship management in order to ensure their customers satisfied. From managers and employees of organizations under study, organizations direct their efforts to satisfy loyal and profitable customers. The results found a positive linkage between customer satisfaction and both customer loyalty and customer profitability.

However, organizations do not consider customer retention seriously in the absence of their profitability. In other words, organizations take three main considerations into their account to guarantee their customer retention: customer satisfaction, customer loyalty and customer profitability. Singh and Singh (2016) reported that the cost of satisfying one customer is less seven times than the cost required to attract a new customer. Additionally, low percent of loyal customers, i.e., 20 percent contributes a high percent, e.g., 80 percent of organization's revenue.

In his work on the relationship between customer relationship management and marketing performance, Soliman (2011) indicates that most of the CRM concepts, i.e., process, strategy, philosophy, technology, and ability are ground on the establishment of profitable long-term relationships with customers on the basis of its ability to adopt in a continuous manner to every customer in order to retain him or her. In relation to customer loyalty, Minna and Aino (2005) identified creating customer loyalty as a major process of CRM. In the same context, Soliman (2011) defined CRM as an approach used to understand customers behaviors in order to increase their loyalty. Kangu et al. (2017) detects a positive influence of CRM as measured by technology infrastructure on customer loyalty. Minna and Aino (2005) mention a main theme of CRM philosophy which is to build and maintain long-term relationships with profitable customers.

All in all, Jha (2008 cited in Wachira and Were, 2016) think of customer retention as an ultimate outcome of CRM. Babatunde and Ajayi (2010) find out that CRM is positively affects customer profitability. Noor (2012) views customer satisfaction and loyalty as intangible components of e-CRM performance, and regard customer retention as a tangible aspect of e-CRM performance. Richards and Jones (2009) list several benefits of CRM based on the results of previous studies; enhanced customer satisfaction. In relation to the direct impact of CRM on customer satisfaction, Singh and Singh (2016) name enhanced customer satisfaction as a main advantage of CRM. 
Table 5. Summary of hypotheses testing results

\begin{tabular}{clc}
\hline & \multicolumn{1}{c}{ Hypothesis } & Result \\
\hline H1 & Customer relationship management is significantly related to customer satisfaction & Supported \\
H2 & Customer loyalty mediates the relationship between customer satisfaction and customer profitability & Rejected \\
H3 & Customer profitability mediates the relationship between customer satisfaction and customer retention & Supported \\
\hline
\end{tabular}

Richards and Jones (2009) state that the enhanced customer satisfaction is one of the most common benefits of CRM. Khedkar (2015) found appositive and significant effect of CRM on customer satisfaction which in turn affects customer loyalty. Despite the significant and direct impact of customer satisfaction on customer loyalty as this study find.

\section{CONCLUSIONS}

\subsection{Recommendations}

CRM results in satisfied customers, which in turn indirectly affects customer retention. The direct relationship is between customer satisfaction and customer loyalty and customer profitability. Therefore, organizations are required to undertake practices directed to attract profitable customers and take into their consideration how to retain those customers. Examples of methods employed this goal is to create loyalty programs, training programs designed to equip the organizational staff with knowledge and skills related to create long-term profitable relationships with customers.

Babatunde and Ajayi (2010), in their study on CRM in banking sector recommend banks to invest more in employee training in order to ensure an effective and efficient use of CRM. In agreement with Kangu et al. (2017), the presents study hold the view that organizations ought to adapt to technology advancements in order to increase their customers loyalty.

\subsection{Limitations and future research}

Despite the importance of the results found by the current study, it still limited to the sample of the study which consists of managers and employees of restaurants only. Researchers are called to use the same constructs in different organizations from different sizes. Another limitation of the study relates to the model of the study, where the direct or indirect relationships between customer relationship management on one side and customer loyalty, customer profitability, and customer retention on the other side. It is recommended to explore the relationship between these variables in the future. For example, further studies are needed to investigate the relationship between CRM and customer loyalty, either directly or indirectly through customer satisfaction. The generalization of the results should be carefully applied, since the study is kept within bounds of restaurants in the capital city, Riyadh. Moreover, the study measured customer satisfaction from managers' and employees' viewpoints. Future study should measure customer satisfaction from customers' perspectives. Based on Garrido-Moreno et al.'s (2014) results, two variables are necessary to ensure the success of CRM, which are organizational commitment and knowledge management. Figure 2 shows a suggested model that researchers should consider in their future studies. 


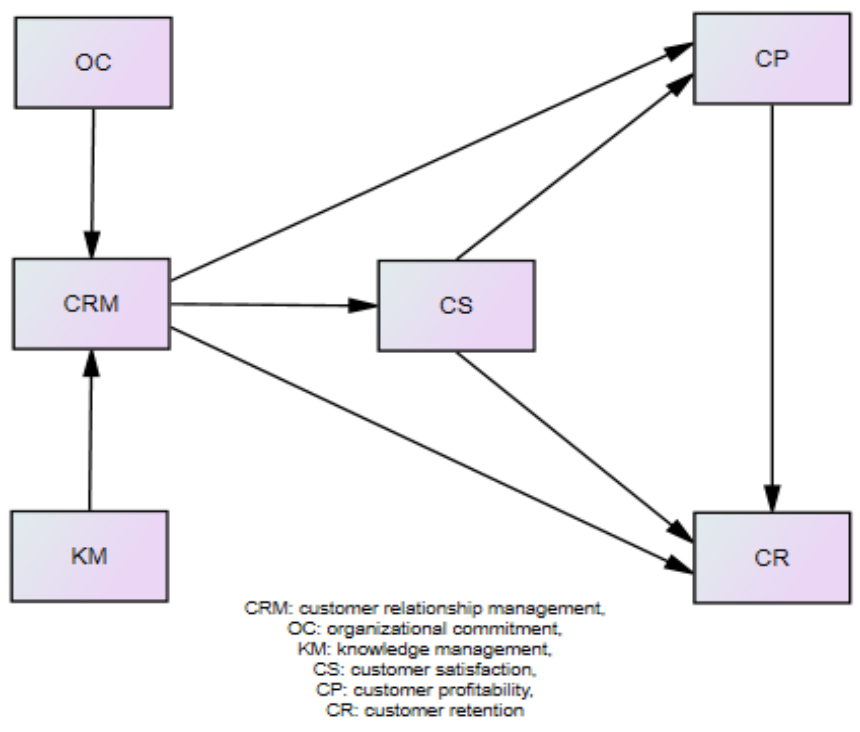

Figure 2. Suggested model for future research

\section{СТУБОВИ ЗАДРЖАВАЊА ПОТРОШАЧА: ЕМПИРИЈСКА СТУДИЈА О УТИЦАЈУ ЗАДОВОЉСТВА, ЛОЈАЛНОСТИ И ПРОФИТАБИЛНОСТИ ПОТРОШАЧА НА ЊИХОВО ЗАДРЖАВАњЕ}

\section{Bader Almohaimmeed}

\section{Извод}

Циљ ове студије је истражити односе између пет фактора: управљање односима са потрошачима, задовољство потрошача, лојалност потрошача, профитабилност и задржавање потрошача. Узорак студије чини 750 менаџера и запослених у различитим ресторанима у Ријаду, главном граду Саудијске Арабије. Упитник састављен за потребе ове студије ручно се делио испитаницима. Од 750 подељених упитника, 497 је враћено се исправним одговорима, што чини високу стопу добијених одговора. Анализа тренутних структура (АМОС, верзија 22) коришћена је за анализу прикупљених података. Резултати ове студије открили значај утицаја управљања односима са потрошачима на задовољство потрошача, као и значајан утицај задовољства потрошача на лојалност и на профитабилност потрошача. Стога, подаци не подржавају хипотезу да лојалност потрошача посредује у односу између задовољства и профитабилности потрошача. Са друге стране, постоје значајни односи између задовољства и профитабилности потрошача и између профитабилности и задржавања потрошача, док не постоји значајна веза између задовољства и задржавања потрошача.

Кључне речи: управљање односима са потрошачима, задовољство потрошача, лојалност потрошача, профитабилност потрошача, задржавање потрошача. 


\section{References}

Adalikwu, C. (2012). Customer relationship management and customer satisfaction. African Journal of Business Management, 6 (22), 6682-6686.

Alipour, M., \& Mohammadi, M. (2011). The effect of customer relationship management (CRM) on achieving competitive advantage of manufacturing tractor. Global Journal of Management and Business Research, 11 (5), 26-35.

Anderson, H., \& Jacobsen P. (2000). Creating loyalty: Its strategic importance in your customer strategy. Pp. 56-67, in S.A. Brown, ed., Customer Relationship Management, Ontario: John Wiley.

Arokiasamy, A. (2005). The impact of customer satisfaction on customer loyalty and intentions to switch in the banking sector in Malaysia. The Journal of Commerce, 5 (1), 14-21.

Ashraf, M., Hamyon, A., Khan, M. Jaafar, N., \& Sulaiman, A. (2015). The impact of involvement in CRM initiative on interfunctional integration and organizational performance: Evidence from Pakistani enterprises. Information Management and Business Review, 7 (1), 29-40.

Babatunde, B., \& Ajayi, E. (2010). The relevance of customer relationship management in the Nigerian banking industry: A case study of International Bank Plc. Information Management, 12, 98-108.

Bahrami, M., Ghorbani, M., \& Arabzad, M. (2012). Information technology (IT) as an improvement tool for customer relationship management (CRM). Procedia - Social and Behavioral Sciences, 41, 59-64.

Bontis, N., Booker, L., \& Serenko, A. (2007). The mediating effect of organizational reputation on customer loyalty and service recommendation in the banking industry. Manage. Decision., 45 (9), 1425-1445.

Boudiaf, I. (2016). The development of competitive advantage in SMEs through (CRM) paradigm: Case study: a sample of agencies of Telecommunication Sector in Algeria. Revue Albahit Al ijtima’i-Nº12, 2944.

Bowen, J., \& Chen, S. (2001). The relationship between customer loyalty and customer satisfaction. International Journal of Contemporary Hospitality Management, 213-217.

Chen, I., \& Popovich, C. (2003). Understanding customer relationship management (CRM)-People, process and technology. Business Process Management Journal, 9 (5), 672-688.

Coldwell, J. (2001). Characteristics of a good customer satisfaction survey. Pp. 193199 in J.N. Sheth, A. Parvatiyar \& G. Shainesh, eds., Customer Relationship Management, New Delhi Tata McGraw-Hill

Dubihlela, J., \& Molise-Khosa, P. (2014). Impact of e-CRM implementation on customer loyalty, customer retention and customer profitability for hoteliers along the Vaal Meander of South Africa. Mediterranean Journal of Social Sciences, MCSER Publishing, Rome-Italy, 5 (16), 175-183.

Dumitrescu, L., \& Fuciu, M. (2009). Customer relationship management. Annals of the University of Petroşani, Economics, 9 (3), 255-260.

ElKordy, M. (2014). The impact of CRM capability dimension on organizational performance. European Journal of Business and Social Sciences, 2 (10), 128-146.

Garrido-Moreno, A., Lockett, N., \& Garcia-Morales, V. (2014). Paving the way for CRM success: The mediating role of knowledge management and organizational 
commitment. Information \& Management, 51, 1031-1042.

Hafeez, S., \& Muhammad, B. (2012). The impact of service quality, customer satisfaction and loyalty programs on customer's loyalty: Evidence from banking sector of Pakistan. International Journal of Business and Social Science, 3 (16), 200209.

Hassan, R., Nawaz, A., Lashari, M., \& Zafar, F. (2015). Effect of customer relationship management on customer satisfaction. Procedia Economics and Finance, 23, 563-567.

Ibojo, B., \& Asabi, O. (2015). Impact of customer satisfaction on customer loyalty: A case study of a reputable bank in Oyo, Oyo State, Nigeria. International Journal of Managerial Studies and Research (IJMSR), 3 (2), 59-69.

Ibojo, B., Olawepo, G., \& Akinruwa, T. (2013). Effect of customer satisfaction on organizational profitability, using an organization in the food and beverage industry. International Journal of Management Sciences, 1 (5), 159-166.

Kangal, A. (2012). Identifying the dominant perspective on customer relationship management in the last decade 2000-2010. Journal of Business 46 Research, 4 (4), 45-61.

Kangu, M., Wanjau, K., \& Kosimbei, G. (2017). Technology infrastructure: A customer relationship management dimension in maintaining customer loyalty. International Journal of Economics, Commerce and Management, V (5), 88-106.

Khedkar, E. (2015). Effect of customer relationship management on customer satisfaction and loyalty. International Journal of Management (IJM), 6 (5), 1-7.

Khodakarami, F., \& Chan, Y. (2014). Exploring the role of customer relationship management (CRM) systems in customer knowledge creation. Information \& Management, 51, 27-42.

Lenskold Group (2003). Retention marketing profitability, ROI challenges influencing the retention versus acquisition debate. Marketing Profitability White Paper Series, 1-20.

Minna, R., \& Aino, H. (2005). Customer knowledge management competence: Towards a theoretical framework. Proceedings of the 38th Hawaii International Conference on System Sciences, IEEE, 1-10. Mohsan, F., Nawaz, M., Khan, M., Shaukat, Z. \& Aslam, N. (2011). Impact of customer satisfaction on customer loyalty and intentions to switch: Evidence from banking sector of Pakistan. International Journal of Business and Social Science, 2 (16), 263-270.

Navimipour, N., \& Soltani, Z. (2016). The impact of cost, technology acceptance and employees' satisfaction on the effectiveness of the electronic customer relationship management systems. Computers in Human Behavior, 55, 1052-1066.

Noor, N. (2012). Trust and commitment: Do they influence e-customer relationship performance? International Journal of Electronic Commerce Studies, 3 (2), 281296.

Pezeshki, V., Mousavi, A., \& Rakowski, R. (2005). Profitability through customer relationship marketing. Proceedings of the International Conference on Computer and Industrial Management, ICIM, October 2930, Bangkok, Thailand.

Piroozfar, S. \& Yaghini, R. (2012). A review: Different views of customer relationship management. Proceedings of the 2012 International Conference on Industrial Engineering and Operations Management Istanbul, Turkey, July 3-6. 
Richards, K., \& Jones, E. (2009). Customer relationship management: Finding value drivers. Industrial Marketing Management, 37, 120-130.

Singh, S., \& Singh, A. (2016). Customer relationship management (CRM)- A statistical perspective. International Journal of Current Research, 8 (2), 26771-26776.

Soliman, H. (2011). Customer relationship management and its relationship to the marketing performance. International Journal of Business and Social Science, 2 (10), 166-182.

Stojkovic, D. \& Dubricic, R. (2012). Customer relationship management concept in the electronic business era. Journal of Engineering Management and Competitiveness (JEMC), 2 (1), 22-26.

Thompson, B. (2005). The loyalty connection: Secrets to customer retention and increased profits. RightNow Technologies, 1-16.

Urbanskiene, R., Žostautienè, D., \& Chreptavičienè, V. (2008). The Model of Creation of Customer Relationship Management (CRM) System. Engineering Economics, 3 (58), 51-59.

Wachira, J., \& Were, S. (2016). Effect of customer relationship management on perceived organizational performance: A case study of family bank limited. The Strategic Journal of Business and Change Management, 3 (2/15), 321-343. 


\section{APPENDIX}

Questionnaire (Likert scale five point)

CRM

1. I feel CRM strategies is mainly concerned with the consumers interests.

2. I feel secured \& satisfied with CRM strategies of the retail outlet.

3. Business is better with CRM rather than without.

4. I think time has come to make use of CRM extensively in retail

5. CRM leads to improve the customer base in retail.

6. I am feeling safe in the transaction

7. This restaurant presents the innovative services

8. This restaurant contacts with me and informs me about new campaigns and services

9. The personnel of this restaurant are sincere, helpful and kind.

10. The personnel of this restaurant understand my demands quickly and fulfil them immediately.

11. The personnel of this restaurant use an easy-to-understand language while giving service.

12. At this restaurant, all the news regarding the customer is collected regularly.

Customer satisfaction

1. I am satisfied with the performance of the employees

2. I am satisfied with the overall services range offered by the retailer.

3. I am satisfied with the overall service quality offered by the retailer.

4. The products and services offered by this restaurant meet my needs.

Customer loyalty

1. I intend to continue using services from this retail outlet for a long time

2. I am willing to say positive things about this retail outlet to other people.

3. I recommend to my friends and colleagues to visit \& purchase through the same retail outlet as I do

4. This restaurant has a positive image

5. I will go on using the same restaurant

6. This restaurant is a leading restaurant in the industry

Customer profitability

1. Good value for the price paid

2. The cost is very acceptable

3. Supposing I were in the area again, I would go to this restaurant.

4. I received the service in shortly time

Customer retention

1. I plan to continue my relationship with this restaurant in future.

2. I would encourage friends and relatives to go to this restaurant.

3. I have said positive things about my restaurant to others.

4. I consider my restaurant as my first choice. 